\title{
Effect of Panchagavya on Growth and Yield: A Review
}

\author{
Chunchu Suchith Kumar* and Gurpreet Singh \\ Department of Agronomy, School of Agriculture, Lovely Professional University, Jalandhar, \\ Punjab, India \\ *Corresponding author
}

\section{A B S T R A C T}

\begin{tabular}{|l|}
\hline Ke y w o r d s \\
Panchagavya, \\
Organic, Foliar, \\
Cow urine
\end{tabular}

\section{Introduction}

Panchagavya is a Sanskrit word that means a blend of five products obtained from cow. The five products include Cow dung + Cow urine + Cow milk + Cow curd and Cow ghee. All these are individually called "Gavya" and altogether called a "Panchagavya".

All these five products are the main components for the preparation of Panchagavya. Along with these, other components like jaggery, sugarcane juice, ripen bananas, yeast and tender coconut water also used to boost the fermentation and support the beneficial micro-organisms growth.

\begin{abstract}
Panchagavya, an ancient Vedic formulation is a blend of five products namely the dung, , milk, curd and ghee obtained from an indigenous cow. All the five components are reducing the initial investment. It is rich in growth enhancing substances like organic compounds, hormones, micro and macro nutrients and minerals besides having antibacterial and insecticidal properties. Panchagavya enhances the productivity by increasing the growth of roots, stems, branches and leaves and related parameters like root length, length, number of branches, number of leaves, leaf area index, chlorophyll content, content and other quality parameters finally contributing to the overall high yield and yield attributes. Thus, it plays an important role in the overall growth and development of crop plants and increase of yield and profits. It is also eco- friendly.
\end{abstract}

\section{Preparation of Panchagavya is as follows}

Natarajan (2002) procedure is as follows: Take fresh cow dung $(7 \mathrm{~kg})$ and cow ghee $(1 \mathrm{~kg})$ and mix them thoroughly and incubate them for two days. Next, add cow urine (3litre) along with 10 litre of water and stir them properly for one week daily at mornings and evenings. Then add sugarcane juice (3 litre) or jaggery mixed in water at the rate of 1:6 ratio. Add cow milk (2 litre), cow curd (2 litre), tender coconut water (3 litre), yeast $(100 \mathrm{~g})$ and ripened banana (12). Stir the solution thoroughly and properly for three weeks daily at mornings and evenings. Finally, Panchagavya is ready and can be used thereafter. 
All the above-mentioned items are to be mixed either in an earthen pot or a concrete tank or a plastic bucket that has a larger mouth and must be kept open in shade.

The ingredients must be added only in the above-mentioned order. Stirring the mixture must be done twice daily and only in the mornings and evenings and should be done only in uni - directional method.

\section{Effect of Panchagavya on growth and development}

Balasubramanian et al., (2001) reported that the enhanced growth and yield were observed in seedlings dippedin panchagavya before transplanting in rice.

Vasumathi (2001) and Sanjutha et al., (2008) concluded that the growth enzymes present in panchagavya might have favoured rapid cell division and multiplication for higher growth characters and increased height in Phyllanthus amarus and Andrographis paniculata respectively.

Beaulah et al., (2002) concluded that the beneficial microorganisms from panchagavya and their presence in the rhizospheres environment of the root zone influence the plant growth and crop yield.

Natarajan (2002) concluded that panchagavya enhanced the growth, vigour and resistance to pests and diseases and further in the enhancement of keeping quality of vegetables and fruits in various crops like turmeric, paddy, onion, gingelly, sugarcane, banana, vegetables and curry leaf.

Subramanian (2005) concluded that the use of traditional panchagavya as manure resulted in the increase of nodule formation by almost $18 \%$ to $62 \%$.
Velmurugan (2005) observed that seed treatment + foliar application of panchagavya $3 \%$ produced the tallest plant height $(26.75$ $\mathrm{cm}$ ), higher number of leaves (14.0) as compared to other treatments in Radish.

Somasundaram and Amanullah (2007) reviewed that panchagavya shows positive effect on growth and productivity of crops.

Mohanalakshmi and Vadivel (2008) concluded that application of poultry manure $\left(5 \mathrm{t} \mathrm{ha}^{-1}\right)+$ panchagavya $(3 \%)$ resulted in the highest root yield of $1354.5 \mathrm{~kg} \mathrm{ha}$ ${ }^{1}$ andproduced higher leaf number per plant in aswagandha.

Sanjutha et al., (2008) concluded that the application of FYM @ 15 t/ha + NPK @ 75: 75: $50 \mathrm{~kg} / \mathrm{ha}+$ panchagavya @ 3\% foliar spray recorded the highest plant height $(54.10$ $\mathrm{cm}$ ), number of branches (27.40), number of leaves (105.67) and highest Leaf Area Index (LAI) (1.03) when compared to other treatments in Kalmegh.

Tharmaraj et al., (2011) concluded thatpanchagavya containing plant growth substances results in the change in phenotypes of plants rapidly for better growth and productivity of crops.

Vennila and Jayanthi (2008) concluded that spraying of $2 \%$ panchagavya $+100 \%$ recommended dose of fertilizer resulted in enhanced plant height $(131.7 \mathrm{~cm})$ and production of dry matter (5.9 g / plant) in okra.

Gore and Srinivas (2011) concluded that significant increase in the plant height and root- length was recorded with the application of recommended dose of fertilizer + beejamruth + panchagavya + jeevamruth in Lycopersicon esculentum (Tomato). 
Nileema et al., (2011) observed that the soil treatment of RDF + beejamruth (seed treatment) + jeevamruth (soil application) + panchagavya $3 \%$ foliar spray showed improvement in plant height $(143.21 \mathrm{~cm})$, root length $(19.80 \mathrm{~cm})$ and dry matter $(7.94$ $\mathrm{g} /$ plant) compared to other treatments and control in tomato.

Saranraj et al., (2011) concluded that application of 3\% panchagavya foliar spray increase physiological growth, leaf area index, dry matter production, chlorophyll content, $\mathrm{N}$ content, yield, yield attributes and economics of black gram.

Suresh et al., (2011) concluded that the foliar application of panchagavya resulted in significant improvement in plant height (42.6 $\mathrm{cm}$ ), number of branches (10) when compared with $\mathrm{N}, \mathrm{P}, \mathrm{K}$ and control in black gram.

Patil et al., (2012) reported that the application of panchagavya $3 \%$ at 15 days after flowering increased plant height (37.01 $\mathrm{cm}$ ), number of branches per plant (5.22), higher leaf area index (1.31) and root nodules (20.50) in chickpea.

Vijaykumari et al., (2012) concluded that the seeds soaked in panchagavya (1\%) and humic acid (1\%) for 8 hours gave higher protein content of the harvested seeds $(1.25 \mathrm{mg} / \mathrm{g}$ tissue) and ascorbic acid content of the harvested seeds $0.48 \mathrm{mg} / \mathrm{g}$ tissue) as compared to other treatments in Soybean.

Amalraj et al., (2013) concluded that the seed treatment with panchagavya resulted in enhanced root and shoot length of $19.4 \mathrm{~cm}$ and $16.9 \mathrm{~cm}$ respectively along with dry mass (147 mg), high leaf area $\left(14.57 \mathrm{~cm}^{2}\right)$, chlorophyll content (23 spad units) and photosynthetic activity after 15 DAS in pigeonpea.

Naik et al., (2013) concluded that panchagavya either in foliar or media application gave better results in growth and spike production in Cymbidium hybrid.

Jain et al., (2014) concluded that panchagavya application increases germination percentage, germination index, root and shoot length, fresh and dry weight of the seedlings, plant height and chlorophyll content besides effecting available macro and micro nutrients like $\mathrm{Zn}, \mathrm{Cu}, \mathrm{Mn}$ and microbial activity as compared with FYM and vermicompost.

Pagar et al., (2016) reported that application of panchagavya influenced the plant height, dry matter accumulation, total and effective tillers significantly in wheat.

Ananda and Murthy (2017) found that the treatment with enriched bio digester at $25 \mathrm{~kg}$ $\mathrm{N}$ equivalent per hectare + panchagavya at $3 \%$ gave higher leaf area index (3.20) at 60 DAS when compared to other treatments in groundnut and finger millet.

Choudhary et al., (2017) reported that application of panchagavya gave the maximum plant height, higher dry matter accumulation, maximum leaf area index at branching and flowering stages in black gram.

By the above data, we can understand that panchagavya enhances the root length, formation of root nodules, plant height, number of branches, number of leaves, chlorophyll content and leaf area index (LAI)contributing to the higher photosynthetic activity thereby increasing fresh and dry weight which might be due to the presence of various growth enzymes which favours rapid cell division and cell- multiplication contributing to the overall growth and development of plants resulting in better yields. Thus, panchagavya plays an important role in the growth and development of plants. 
Effect of Panchagavya on yield and yield attributes

Vivekanandan (1999) concluded that the spray of panchagavya resulted in doubling the stick yield apart from pest and disease resistance in moringa.

The increased yields were also observed in crops like Chilli by Subhashini et al., (2001); in Moringa by Beaulah et al., (2002); in Green gram by Somasundaram et al., (2003) and in French bean by Selvaraj, (2003) with the use of panchagavya.

Kanimozhi, (2003) observed that spraying of $4 \%$ panchagavya was found to give superior yield with respect to root yield i.e., 2.5times $\mathrm{kg} / \mathrm{plot}$, when compared to control in Coleus forskohili.

Somasundaram et al., (2003) observed that there was significantly higher number of seeds per pod (12.9) and grain yield (17.87 $\mathrm{q} / \mathrm{ha}$ ) recorded with panchagavya $3 \%$ as compared to other treatments in green gram.

Birendra and Christopher, (2007) noted that the foliar application of 3\% panchagavya resulted in significant increase in yield attributes.

Swaminathan et al., (2007) concluded that foliar application of 3\% panchagavya at 15 , 25 and 40 DAS recorded the highest grain yield $(1195 \mathrm{~kg} / \mathrm{ha})$ in black gram.

Mohanalakshmi and Vadivel, (2008) concluded that application of poultry manure $\left(5 \mathrm{t} \mathrm{ha}^{-1}\right)+3 \%$ panchagavya registered the highest root yield of $1354.50 \mathrm{~kg} \mathrm{ha}^{-1}$ in aswagandha.

Sanjutha et al., (2008) concluded that the application of FYM @ $15 \mathrm{tha}^{-1}$ + NPK @ 75: 75: $50 \mathrm{~kg} / \mathrm{ha}+$ panchagavya @ 3\% foliar spray recorded significantly higher dry leaf yield $(619.06 \mathrm{~kg} / \mathrm{ha})$ and dry herbage yield $(1993.10 \mathrm{~kg} / \mathrm{ha})$ as compared to other treatments in Kalmegh (Andrographis paniculata).

Vennila and Jayanthi, (2008) observed that application of panchagavya resulted in the increase of fruit number per plant, fruit weight (gram/fruit) and yield (quintals/ hectare) in Okra.

Mudigora et al., (2009) concluded that among different treatments, panchagavya + NSKE (5\%) recorded highest yield of $14.16 \mathrm{q} / \mathrm{ha}$ followed by NSKE + cow urine (5\%) (12.59 $\mathrm{q} / \mathrm{ha})$, panchagavya $+V$. negundo (12.45) and $V$. negundo + cow urine $(12.04 \mathrm{q} / \mathrm{ha})$ and panchagavya + P. glabra @ 5\% (12.40 q/ha).

Kumawat et al., (2010) concluded that the foliar application of neem + panchagavya increased yield in cluster bean and cumin. In comparison to cluster bean - cumin system, higher cumin equivalent yield was recorded under groundnut - cumin system with neem + panchagavya $(1259 \mathrm{~kg} / \mathrm{ha})$ followed by tumbo + panchagavya (1068 kg/ha).

Ravi et al., (2011) concluded that the treatment RDF + panchagavya spray $3 \%$ at 30, 60 and 75 days after sowing showed higher oil percentage (40.7), protein percentage (22.4), oil yield $(685.1 \mathrm{~kg} / \mathrm{ha})$ and protein yield $(377.7 \mathrm{~kg} / \mathrm{ha}$ ) as compared to other treatments in ground nut

Sunil et al., (2012) reported that application of neem + panchagavya spray at $30 \%, 54 \%$ and $80 \%$ at 55 and 80 days after sowing recorded higher plant dry matter compared to control in cumin crop.

Vimalendran and Wahab (2013) observed that four sprays of panchagavya $3 \%$ at $15,25,35$ and 45 DAS showed higher number of cobs (2.95), cob length $(26.66 \mathrm{~cm})$, cob width (4.46 $\mathrm{cm})$, individual cob weight (29.69 $\mathrm{g}$ ) and 
yield $(7476 \mathrm{~kg} / \mathrm{ha})$ as compared to other treatments in baby corn.

Sakubai et al., (2014) recommended that the organic treatment (VAM + panchagavya + amritpani@3\% drench and spray) for enhanced growth and yield of buck- wheat.

Waghmode et al., (2015) found that treatments with cow urine spray $10 \%$ and panchagavya spray 3\% at grand growth period and tasseling stages gave higher protein content $(9.27 \%$ and $9.21 \%)$, higher fresh cob yield ( $5078 \mathrm{~kg} / \mathrm{ha}$ and $5262 \mathrm{~kg} / \mathrm{ha}$ ), fresh grain weight (166.1 $\mathrm{g}$ and $169.8 \mathrm{~g}$ ), dry grain weight per plant $(69.85 \mathrm{~g}$ and $70.66 \mathrm{~g})$, cob girth $(13.89 \mathrm{~cm}$ and $13.71 \mathrm{~cm})$ and $\mathrm{cob}$ length $(13.29 \mathrm{~cm}$ and $12.88 \mathrm{~cm})$ compared to other treatments in sweet corn.

Boraiah et al., (2017) concluded that panchagavya spray resulted in the attainment of significant yield per hectare and higher shelf life of 18.58 days and higher capsaicin content of $0.32 \%$ in capsicum.

Gopal et al., (2017) stated that the panchagavya (4\%) spray showed significantly higher dry matter, leaf area index (LAI), number of pods, number of seeds, seed yield, straw yield and biological yield in black gram.

Suchitra et al., (2017) observed that3\% panchagavya spray resulted in the highest number of fruits (19)and fruit weight (30.67 $\mathrm{mg} /$ fruit) when compared with other treatments in Abelmoschus esculentus.

By the above data, the crops treated with panchagavya resulted in the attainment of better and higher yields. The yield also showed better yield quality parameters like higher dry matter content, protein content, fresh and dry weights, root yield, number of fruits, fruit weight, seed and grain weight, cob- length and girth, oil content, and protein content. Thus, Panchagavya plays an important role in the yield and yield attributes of a wide variety of crops.

In conclusion the panchagavya enhances the productivity through the increase in growth of roots, stems, branches and leaves and related parameters like root length, stem length, number of branches, number of leaves, leaf area index, chlorophyll content, oil content, protein content and other quality and yield parameters. Thus, Panchagavya plays a very important role in the growth and development of plants and contributes to better yield and yield attributes when compared with other treatments. Preparation of panchagavya is easy and decrease the investment cost and on the other hand it gives high net- returns which helps to attain high $\mathrm{B}: \mathrm{C}$ ratio to the farmer. Panchagavya is safe and eco-friendly and contributes to sustainability.

\section{References}

Amalraj, D.L., Kumar, G.P., Ahmed, S.K.M., and Kishore, N. 2013.Microbiological analysis of Panchagavya, vermicompost, and FYM and their effect on plant growth promotion of pigeon pea (Cajanus cajan L.) in India. Organic Agriculture. 3(1): 23-29.

Ananda, S.M.R., and Murthy, K.N.K. 2017. Response of finger millet under organic nutrient management in groundnut (Arachis hypogaea L.) - Finger millet (Eleusine coracana L.) cropping system. International Journal of Pure \& Applied Biosciences. 5(5):200-206.

Balasubramanian, A.V., Vijayalakshmi. K., Sridhar, S., and Arumugasamy, S. 2001. Vrikshayurveda experiments linking ancient texts farmers practices. Compas Magazine march. pp: 39.

Beaulah, A. 2001. Growth and development of moringa (Moringa oleifera Lam.) 
under organic and inorganic systems of culture. Ph.D. Thesis, Tamil Nadu Agricultural University, Coimbatore, 2001

Birendra, K.Y., and Christopher, L.A. 2007. Use of panchagavya as a growth stimulant and biopesticide in agriculture. In: Agriculture and Environment. A Kumar (ed.). APH Publishing Corporation, New Delhi., pp. 65-70.

Boraiah, B., Devakumar, N., and Palanna, K.B. 2018. Yield and Quality Parameters of Capsicum (Capsicum annиит L. var. grossum) as Influenced by Organic Liquid Formulations. International Journal of Current Microbiology and Applied Sciences. 6(1): 333-338).

Gopal Lal Choudhary, S.K. Sharma, Kendra Pal Singh, Sanju Choudhary and Bazaya, B.R. 2017. Effect of Panchagavya on Growth and Yield of Organic Black gram [Vigna mungo (L.) Hepper].International Journal of Current Microbiology and Applied Sciences. 6(10): 1627-1632.

Gore, N.S., and Sreenivasa, M.N. 2011. Influence of liquid organic manures on growth, nutrient content and yield of tomato (Lycopersicon esculentum Mill.) in the sterilized soil. Karnataka Journal of Agricultural Sciences.24(2): 153-157.

Jain, P., Sharma, R., Bhattacharyya, P and Banik, P. 2013. Effect of new organic supplement (Panchgavya) on seed germination and soil quality. Environmental monitoring and assessment. 186. 10.1007/s10661-0133513-8.

Kanimozhi, S., 2003. Organic production package of Coleus forskohili. M.Sc. Thesis, Horticultural College and Research Institute, Tamil Nadu Agricultural University, Coimbatore.
Kumawat, R.N., Mertia, R.S. and Mahajan, S.S. 2010. Comparative performance of groundnut-cumin and cluster beancumin cropping systems under foliar application of panchgavya in western Rajasthan. Annals of Arid Zone. 49(1):31-38.

Mohanalakshmi, M and Vadivel, E. 2008. Influence of organic manure and bioregulators on growth and yield of aswagandha. International Journal of Agriculture Sciences. 2: 429-432.

Mudigora, S. Shekarappa and Balikai, R.A. 2009. Evaluation of plant products in combination with cow urine and panchagavya against sorghum shoot fly, Atherigona soccata Rondani. Karnataka Journal of Agricultural Sciences.22(3Spl. Issue ) : (618-620).

Naik, S., Barman, D., Devadas, R and Bharathi, U. 2013. Evaluation of panchgavya as a source of nutrient for Cymbidium orchids. African journal of agricultural research. 8. 5728-5732.

Natarajan, K.2002. Panchagavya-A Manual. Other Indian Press, Mapusa, Goa, India, pp: 333.

Nileema, S.G., and Sreenivasa M.N. 2011. Influence of liquid organic manures on growth, nutrient content and yield of tomato (Lycopersicon esculentum Mill.) in the sterilized soil. Karnataka Journal of Agricultural Sciences. 24(2):153-157.

Pagar, R. D., Patel, M. M and Munde, S. D. 2015. Influenced of panchagavya on growth and yield of wheat. Agriculture for Sustainable Development. 3(1):5759.

Patil. S.V., Halikatti, S.I., Hiremath, S.M., Babalad, H.B., Sreenivasa, M.N., Hebsur, N.S. 2012. Effect of organics on growth and yield of chickpea (Cicer arietinum L.) in vertisols. Karnataka Journal of Agricultural Sciences. 25(3):326-331. 
Prabhu, M.J., 2009. Panchagavya: low cost organic input for both crops and animals.In: Farmer's Notebook. The Hindu Online Edition, 4th June, 2009.

Ravi, H.S.K., Venkate Gowda, J., Sridhar, D and Poornima, D.S. 2011. Effect of integrated organic sources of nutrients on quality and economics of groundnut (Arachis hypogaea L.).Advance Research Journal of Crop Improvement. 2(1):81-85.

Sakhubai, H.T., Laxminarayana, $\mathrm{H}$ and Chaya, P. 2014. Effect of bio-inoculants and bioformulations on growth, yield and quality of buckwheat. International Journal of Agricultural Sciences and Veterinary Medicine. 2(4): 2320-3730.

Sangeetha, V., and Thevanathan, R. 2010. Biofertilizer Potential of Traditional and Panchagavya Amended with Seaweed Extract. The Journal of American Science. 6(2):61- 67.

Sanjutha S., Subramanian S., Rani, I and Maheswari. 2008.Integrated Nutrient Management in Andrographis paniculata. Research Journal of Agriculture and Biological Science. 4(2): 141-145.

Saranraj, P., (2011). Growth and development of black gram (Vigna mungo) under foliar application of Panchagavya as organic source of nutrient. Current Botany. 2(3):09-11, 2011.

Selvaraj, N. (2003). Report on the work done on organic farming at Horticultural Research Station. Tamil Nadu Agricultural University, Ooty, India. pp: $2-5$.

Somasundaram, E., and Amanullah, M.M. 2007. Panchagavya on growth and productivity of crops: A review. Green Farming. 1:22-26.

Somasundaram, E., Sankaranan, N, Meena, S, Thiyagarajan, T. M, Chandaragiri, K., Pannerselvam, S. 2003. Response of green gram to varied levels of
Panchagavya (organic nutrition) foliar spray. Madras Agricultural Journal. 90: 169-172.

Subhasini, S., Arumugasamy, A., Vijayalakshmi, K., and Balasubramanian, A.V. 2001. Vrikshayurveda- Ayurveda and plants. Centre of Indian Knowledge system, Chennai, India. pp: 33.

Subramanian, A., 2005. Effect of Panchagavya on Escherichia coli in procured milk. Indian Veterinary journal. 82: 799-800.

Suchitra Rakesh, S. Poonguzhali, B. Saranya, S. Suguna and Jothibasu, K. 2017. Effect of Panchagavya on Growth and Yield of Abelmoschus esculentus cv. Arka Anamika. International Journal of Current Microbiology and Applied Sciences.6(9): 3090-3097.

Sunil, S.M., Kumawat, R.N and Mertia, R.S. 2012. Organic seed production of cumin (Cuminum cyminum L.) with foliar application of panchgavya and plant leaf extracts in arid western Rajasthan. Int. $J$ Seed Spices. 2(2):19-26.

Swaminathan, C., Swaminathan, V and Vijayalakshmi, K. 2007. Panchagavya Boon to organic Farming. International Book, Distributing Co., Lucknow.

Tharmaraj, K., Ganesh, P., Sureshkumar, R., Anandan, A and Kolanjinathan, K. 2011. A Critical Review on Panchagavya - A Boon Plant Growth. International Journal of Pharmaceutical and Biological Archive. 2(6):1611-1614.

Vasumathi, R., 2001. Influence of organic manures, biofertilizers and plant density on growth, yield and alkaloid content of Bhumyamalaki (Phyllanthus amarus Schum. and Thonn.). M.Sc., (Horticulture) Thesis Tamil Nadu Agricultural University, Coimbatore, India. 
Velmurugan, M. 2005. Studies on organic farming practices on growth, yield and quality of radish (Raphanus sativus L.) cv. Pusa chetki. South Indian horticulture. 53(1-6):337-339.

Vennila, C., and Jayanthi, C. 2008. Response of Okra to integrated nutrient management. Journal of Soils and Crops. 18: 36-40.

Vijakumari, B., Hiranmai, Y.R, Gowri, P., Kandari, L.S. 2012. Effect of panchagavya, humic acid and micro herbal fertilizer on yield and postharvest soil of soya bean (Glycine max L.). Asian Journal of Plant Sciences. 11(2):83-86.
Vimalendran, L., and Wahab, K. 2013. Effect of foliar spray of panchagavya on yield attributes, yield and economic of baby corn. Journal of Agronomy. 12(2):109112.

Vivekanandan, P. 1999.Panchagavya advances paddy harvest by 10 days. Agri News. 2:11.

Waghmode, B.R., Sonawane, S.V and Tajane, D.S. 2015. Differential responses of yield and quality to organic manures in sweet corn [Zea mays (L.) saccharata]. International Journal of Agricultural Science. 11(2):229-237.

\section{How to cite this article:}

Chunchu Suchith Kumar and Gurpreet Singh. 2020. Effect of Panchagavya on Growth and Yield: A Review. Int.J.Curr.Microbiol.App.Sci. 9(12): 617-624.

doi: https://doi.org/10.20546/ijcmas.2020.912.073 